\title{
FUNGAL HYPHAL DYNAMICS IN A WESTERN OREGON DOUGLAS-FIR STAND
}

\author{
Gary A. Hunt \\ School of Forestry, Department of Forest Science, Oregon State University, Corvallis, OR 97331, U.S.A. \\ and \\ ROBERT FOGEL \\ University of Michigan Herbarium, Ann Arbor, MI 48109, U.S.A.
}

(Accepted 10 February 1983)

\begin{abstract}
Summary-Total length and biomass of fungal mycelium in the soil of a young stand of second-growth Douglas-fir in the central Oregon Coast Range were estimated over 27 months with the agar-film technique. Mycelial mass was at maximum in fall and spring and significantly lower in summer. Melanized hyphae dominated other colors, averaging $66 \%$ of monthly litter and $73.7 \%$ of soil hyphal weight. The mycorrhizal fungus Cenococcum geophilum Fr. had significantly larger average diameter than other hyphae and contributed from 1.2 to $64.8 \%$ of the monthly hyphal volume. Multiple regression analyses with temperature, moisture, and litterfall produced no adequate predictive equations for monthly fungal biomass. Large biomass fluctuations over short periods necessitate frequent sampling and long-term study to fully assess the importance of fungal hyphae in ecosystems.
\end{abstract}

\section{INTRODUCTION}

Litlle is yet known about the distribution of fungal hyphae in coniferous forest soils, though data on mycelial biomass are important to understanding the contribution fungi make in decomposition and nutrient cycling, and as mycorrhizal symbionts. We have reported the allocation of biomass and turnover time for fungi in a young, second-growth stand of western Oregon Douglas-fir and have described the contribution of fungi to nutrient cycling in the same stand (Fogel and Hunt, 1979, 1983). We here report an extended study of 27 consecutive months of litter and soil analysis, and describe monthly biomass fluctuations and seasonal changes in fungal hyphae throughout the soil profile.

\section{MATERIALS AND METHODS}

\section{The site}

The 1.2-ha Dinner Creek site is $11.3 \mathrm{~km}$ southwest of Philomath, Oregon, U.S.A. at $44^{\circ} 28^{\prime} 30^{\prime \prime} \mathrm{N}$, $123^{\circ} 29^{\prime} \mathrm{W}$ and at $305-\mathrm{m}$ elevation. Aspect is south; slope ranges from 0 to $60 \%$ (mean $40 \%$ ). The area is characterized by warm, dry summers and mild, wet winters without extensive snow cover (mean temperatures $2.7^{\circ} \mathrm{C}$ in January and $18.5^{\circ} \mathrm{C}$ in July). Annual precipitation averages $1905 \mathrm{~mm}$ but was substantially below average $(848 \mathrm{~mm})$ during the first year of the study (September 1976 to August 1977) and slightly below $(1775 \mathrm{~mm})$ during the second year. Maximum predrawn plant moisture stress of the overstory reached $-1.35 \mathrm{MPa}$ in September 1977 and $-0.99 \mathrm{MPa}$ in September 1978 .

The stand, an overstocked, second-generation forest of 35- to 50-yr-old Douglas-fir [Pseudotsuga menziesii (Mirb.) Franco], was established naturally after clearcutting and burning. Douglas-fir stems greater than $10.2 \mathrm{~cm}$ dia at $1.3 \mathrm{~m}$ aboveground number $1626 \mathrm{ha}^{-1}$ (basal area $45.9 \mathrm{~m}^{-2} \mathrm{ha}^{-1}$ and bole volume $423 \mathrm{~m}^{-3} \mathrm{ha}^{-1}$ ). A few golden chinquapin [Castanopsis chrysophylla (Dougl.) A Dc.] and red alder (Alnus rubra Bong.) are scattered in the understory (basal area $3.2 \mathrm{~m}^{-2} \mathrm{ha}^{-1}$ ). The sparse, shaded understory consists of a few Oregon grape (Berberis nervosa Pursh) and bear-grass [Xerophyllum tenax (Pursh) Nutt.].

The Bohannon soil type of the site is a welldrained, moderately deep ( $100 \mathrm{~cm}$ to bedrock), gravelly loam formed on colluvial materials weathered from Tyee sandstone (Knezevich, 1975). Poorly developed organic layers, averaging $1.8 \mathrm{~cm}$ in depth, are a mull humus type. The $A_{00}(L)$ horizon, a thin layer of freshly fallen needles, is underlain by a scant $A_{01}$ (F) layer. The $\mathrm{A}_{02}(\mathrm{H})$ horizon, well mixed with surface mineral soil by the activity of earthworms and microarthopods, forms a soft, friable $A_{1}$ horizon down to $25 \mathrm{~cm}$. This zone of maximum rooting contains about $18 \%$ pebbles. The $\mathrm{A}_{3}$ horizon extends from 25 to $45 \mathrm{~cm}$ and forms a smooth boundary with the $B$ horizon, which extends to $90-110 \mathrm{~cm}$. A distinctive feature of the Bohannon series is a buried A horizon found between $60-90 \mathrm{~cm}$ which contributes increased organic matter at the base of the profile. Average carbon (measured by loss on ignition at $850^{\circ} \mathrm{C}$ for $4 \mathrm{~h}$ ) is: $0-20 \mathrm{~cm}, 2.91 \% ; 20-40 \mathrm{~cm}, 1.44 \%$; $40-60 \mathrm{~cm}, \quad 0.57 \% ; \quad 60-80 \mathrm{~cm}, \quad 1.38 \% ; \quad 80-100 \mathrm{~cm}$, $0.56 \%$. All horizons are strongly acid: $\mathrm{pH} 5.5$ in the litter layer and 5.7 in the $A_{1}$ horizon.

\section{Sampling and preparation method}

Mycelial length was measured by the Jones and Mollison (1948) agar-film technique as modified by Nagel-de Boois and Jansen (1971). Litter and mineral soil samples to $5 \mathrm{~cm}$ deep were collected on the first of each month at five sampling stations. Samples were 
also taken seasonally at $20-\mathrm{cm}$ increments to a depth of $1 \mathrm{~m}$ at three randomly chosen locations. A portion of each sample ( $2 \mathrm{~g}$ litter or $5 \mathrm{~g}$ soil) was combined with $50 \mathrm{ml}$ distilled water, then homogenized in a Waring knife blender (litter solutions $10 \mathrm{~min}$ and soil solutions $5 \mathrm{~min}$ ). The supernatant was added to $50 \mathrm{ml}$ of hot $2.5 \%$ water-agar and mixed at low speed on a magnetic stirring plate as samples were pipetted into the well of a Howard mold-counting chamber producing a film $0.1 \mathrm{~mm}$ deep. The films were stained for $1 \mathrm{~h}$ in phenolic aniline blue, rinsed with $95 \% \mathrm{ETOH}$, and examined with phase-contrast microscony $(1000 \times)$.

Each month, we observed 20 randomly chosen fields on each of two slides, one for litter and one for soil, from each of the five stations. Hyphal lengths and diameters were measured with a net micrometer disc. All lengths were expressed as $\mathrm{m} \mathrm{g}^{-1}$ dry weight (dw) soil.

To convert mycelial length to biomass, the mean monthly biovolume over 20 sample fields of litter and surface soil was first calculated by computer with the formula of Båăth and Söderström (1979b):

$$
\text { mean biovolume }\left(\mu \mathrm{m}^{-3}=\sum^{20} \frac{\mathrm{d}_{i}^{2}}{2} \times \pi \times 1 i / 20,\right.
$$

where $d_{i}$ is diameter and $l_{i}$ is length of individual hyphal fragments in micrometers. The resulting values were converted to $\mathrm{mm}^{3} \mathrm{~g}^{-1} \mathrm{dw}$ soil.

For seasonal samples from different depths in the soil profile, we used mean hyphal diameters determined from the agar-film preparations: $3.0 \mu \mathrm{m}$ for 10,30 and $50 \mathrm{~cm}$ and $2.7 \mu \mathrm{m}$ for 70 and $90 \mathrm{~cm}$. Thus, volume $\left(\mathrm{mm}^{3} \mathrm{~g}^{-1} \mathrm{dw}\right.$ soil $)=$ hyphal length $\left(\mathrm{m} \mathrm{g}^{-1}\right) \times \mathrm{r}^{2} \times 10^{-3}$.

For conversion of biovolume to biomass ( $\mathrm{mg} \mathrm{g}^{-1}$ ), we used the factors fresh weight hyphal density $=1.1 \mathrm{~g} \mathrm{~cm}^{-3} \quad$ (Saitô, 1955) and dry weight mycelium $=15 \%$ wet weight (Cochrane, 1958; de Boois, 1976). Thus, biomass $\left(\mathrm{mg} \mathrm{g}^{-1}\right)=$ volume $\left(\mathrm{mm}^{3} \mathrm{~g}^{-1}\right) \times 1.1 \times 0.15$. Horizon weights from measurements of whole-soil bulk density, $1903.4 \mathrm{~g} \mathrm{~m}^{-2}$ for litter and $34 \times 10^{3} \mathrm{~g} \mathrm{~m}^{-2}$ for surface soil, were used to convert hyphal biomass from $\mathrm{mg} \mathrm{g}^{-1}$ to $\mathrm{g} \mathrm{m}^{-2}$. Soil weights (based on bulk density samples) used for seasonal profile samples are given in Table 1.

\section{RESULTS}

\section{Hyphae in litter and surface soil}

Litter hyphal length (Fig. 1A) was high in fall and spring and low in summer and winter throughout the study. Maximum length recorded (November 1976) was $12,502 \pm 2131 \mathrm{~m} \mathrm{~g}^{-1} \mathrm{dw}$ litter. Minimum length (August 1978) was $2831 \pm 271 \mathrm{~m} \mathrm{~g}^{-1}$. Litter hyphal weight (Fig. 1B) peaked twice during the study: at $22.13 \pm 5.8 \mathrm{mg} \mathrm{g}^{-1} \quad$ (November 1976) and $23.17 \pm 7.2 \mathrm{mg} \mathrm{g}^{-1}$ (March 1978), the maximum reached during the study. Minimum weight was $5.19 \pm 1.2 \mathrm{mg} \mathrm{g}^{-1}$ (August 1978).

Soil hyphae fluctuated seasonally but neither length nor weight decreased during winter 1977-1978. After July 1977, hyphal length (Fig. 2A) increased to a peak in April 1978 of $749 \pm 122 \mathrm{~m} \mathrm{~g}^{-1}$. Minimum length was $181 \pm 34 \mathrm{mg}^{-1}$ reached in August 1978. Weight of soil hyphae (Fig. 2B) followed a similar pattern, increasing during the winter of 1977-1978 to a peak in April of $1.50 \pm 0.36 \mathrm{mg} \mathrm{g}^{-1}$. The summer low occurred in August 1978 at $0.35 \pm 0.11 \mathrm{mg} \mathrm{g}^{-1}$.

\section{Vertical distribution of soil hyphae}

Hyphae were sampled to $1-\mathrm{m}$ depth in winter, spring, and summer; but because fall samples were lost in an electrical failure, data for fall (to $50 \mathrm{~cm}$ ) were estimated from linear regression equations with soil moisture and temperature as independent variables. Hyphal length fluctuated most near the surface-the annual range from 141 to $750 \mathrm{mg} \mathrm{g}^{-1}$ (Fig. 3). Distinct seasonal differences occurred down to $50 \mathrm{~cm}$, where hyphal lengths ranged from 118 to $264 \mathrm{~m} \mathrm{~g}^{-1}$. Below $50 \mathrm{~cm}$, hyphal mass remained fairly stable, about $80 \mathrm{~m} \mathrm{~g}^{-1}$ at $70 \mathrm{~cm}$ and $38 \mathrm{~m} \mathrm{~g}^{-1}$ at $90 \mathrm{~cm}$. The mean curve from six sampling dates shows a highly significant negative logarithmic correlation with depth (Fig. 3). Maximum and minimum mycelial length and weight (Table 1) generally decreased with increasing depth. Minimum weight increased from the surface down to $60 \mathrm{~cm}$ $\left(6.47-28.12 \mathrm{~g} \mathrm{~m}^{-2}\right)$, then decreased to $2.19 \mathrm{gm}^{-2}$ at $90 \mathrm{~cm}$.

\section{Color groups}

Hyphae were categorized by color after staining with phenolic aniline blue into "melanized" (brown,

Table 1. Soil weight and range in hyphal length and weight in the soil profile at Dinner Creek, Oregon

\begin{tabular}{|c|c|c|c|c|}
\hline \multirow{2}{*}{$\begin{array}{l}\text { Sampling } \\
\text { depth }\end{array}$} & \multirow{2}{*}{$\begin{array}{c}\text { Soil weight } \\
\left(\mathrm{g} \mathrm{m}^{-2}\right)\end{array}$} & \multirow{2}{*}{$\begin{array}{l}\text { Hyphal length } \\
\left(\mathrm{m} \mathrm{g}^{-1}\right)\end{array}$} & \multicolumn{2}{|c|}{ Hyphal weight } \\
\hline & & & $\left(\mathrm{mg} \mathrm{g}^{-1}\right)$ & $\left(\mathrm{g} \mathrm{m}^{-2}\right)^{1}$ \\
\hline $\mathbf{A}_{\mathbf{0 0}} / \mathbf{A}_{01}$ & 1903.4 & $2831-12,502$ & $3.400-15.03$ & $6.47-28.61$ \\
\hline$A_{1} 0-20 \mathrm{~cm}$ & $136 \times 10^{3}$ & $141-750$ & $0.170-0.90$ & $23.12-122.40$ \\
\hline$A_{1} 20-40 \mathrm{~cm}$ & $188 \times 10^{3}$ & $113-456$ & $0.136-0.55$ & $25.57-103.40$ \\
\hline B $40-60 \mathrm{~cm}$ & $198 \times 10^{3}$ & $118-264$ & $0.142-0.32$ & $28.12-63.36$ \\
\hline B $60-80 \mathrm{~cm}$ & $164 \times 10^{3}$ & $69-79$ & $0.0672-0.077$ & $11.02-12.63$ \\
\hline B $80-100 \mathrm{~cm}$ & $150 \times 10^{3}$ & $15-38$ & $0.0146-0.037$ & $2.19-5.55$ \\
\hline
\end{tabular}

$\mathrm{g} \mathrm{m}^{-2} \times 10=\mathrm{kg} \mathrm{ha}^{-1}$.

Table 2. Mean weight and proportion of total weight $(\% \pm S E)$ of hyphae of three color categories at Dinner Creek, Oregon

\begin{tabular}{lcccccc}
\hline & \multicolumn{2}{c}{ Blue-stained } & $\begin{array}{c}\text { Melanized } \\
\left(\mathrm{mg} \mathrm{g}^{-1}\right)\end{array}$ & $(\%)$ & $\left(\mathrm{mg} \mathrm{g}^{-1}\right)$ & \multicolumn{2}{c}{ Other } & $(\%)$ \\
\hline Litter & $3.3(0.23)$ & 24.3 & $8.2(0.40)$ & 66.0 & $1.26(0.43)$ & 9.7 \\
Soil (top 5 cm) & $0.14(0.01)$ & 16.7 & $0.6(0.04)$ & 73.7 & $0.07(0.035)$ & 9.6 \\
\hline
\end{tabular}



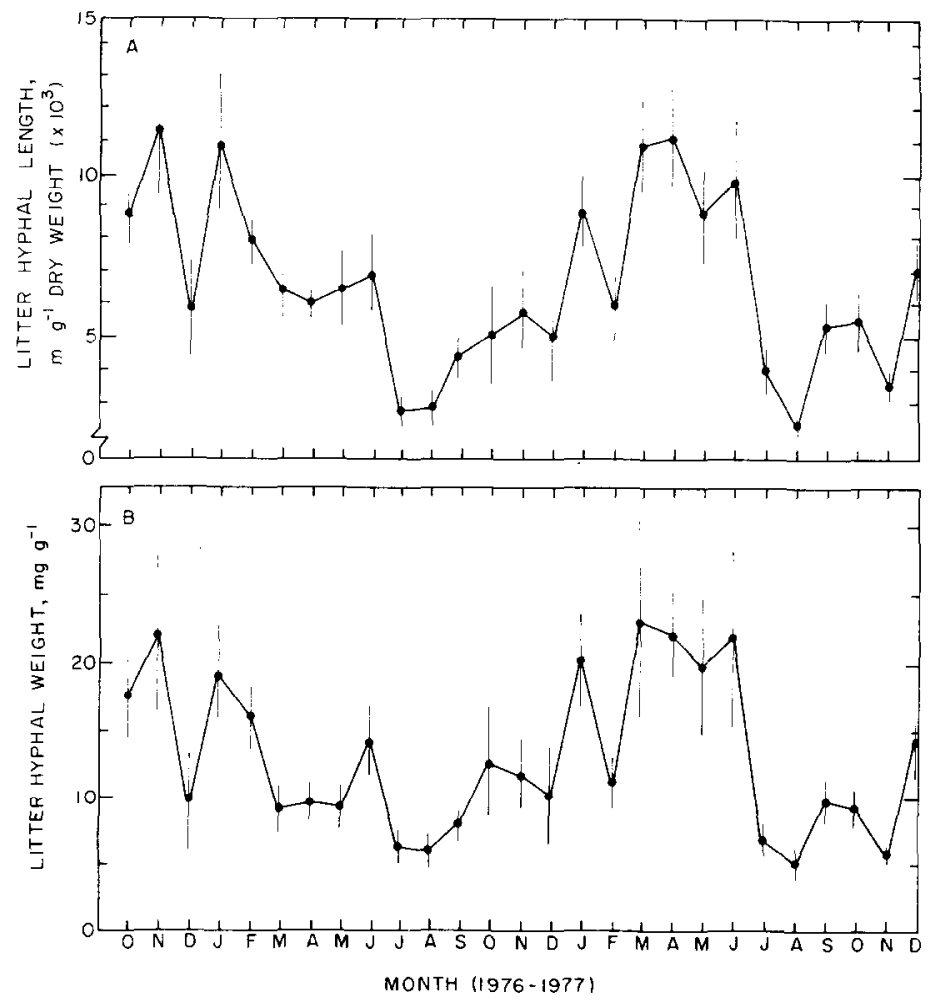

Fig. 1. Total monthly length (A) and weight (B) of hyphae in litter at Dinner Creek, Oregon. Bars indicate standard error of five samples.
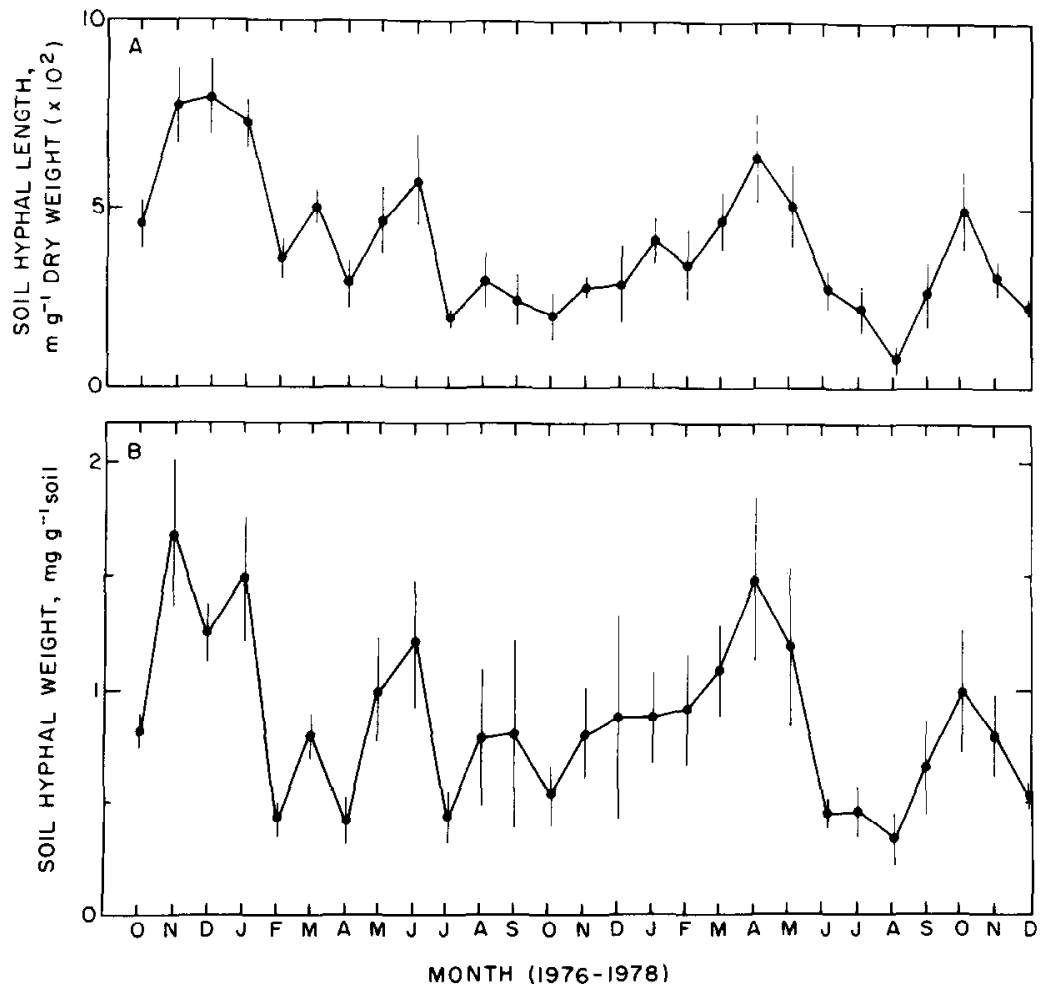

Fig. 2. Total monthly length (A) and weight (B) of hyphae in soil at Dinner Creek, Oregon. Bars indicate standard error of five samples. 


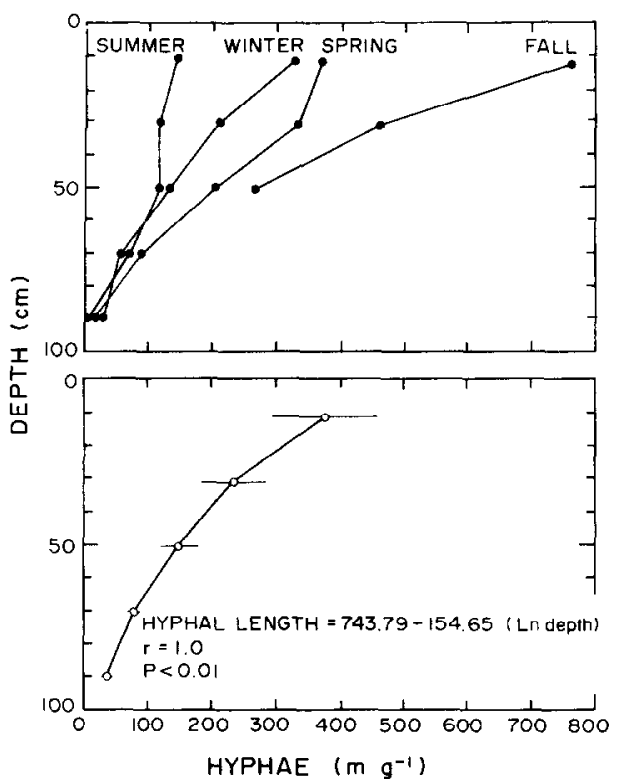

Fig. 3. Seasonal length (top) and mean annual length (bottom) of hyphae at different soil depths at Dinner Creek, Oregon. Horizontal bars are standard error of six samples.
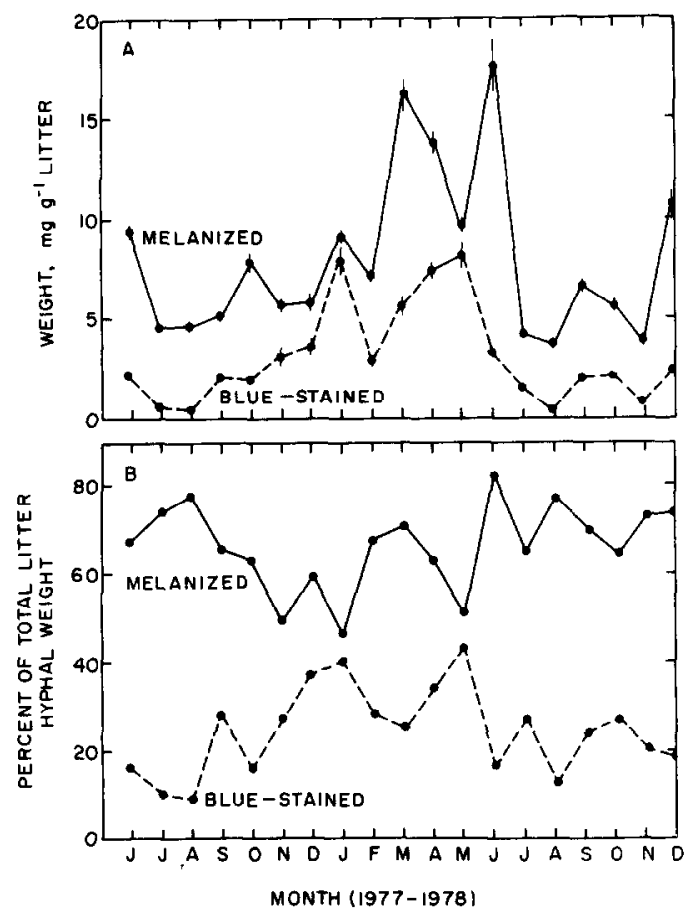

Fig. 4. Monthly weight (A) and percent of total weight (B) of melanized and blue-stained hyphae in litter at Dinner Creek, Oregon. Bars in A indicate standard error; missing bars indicate standard error is $<4 \%$ of the mean.
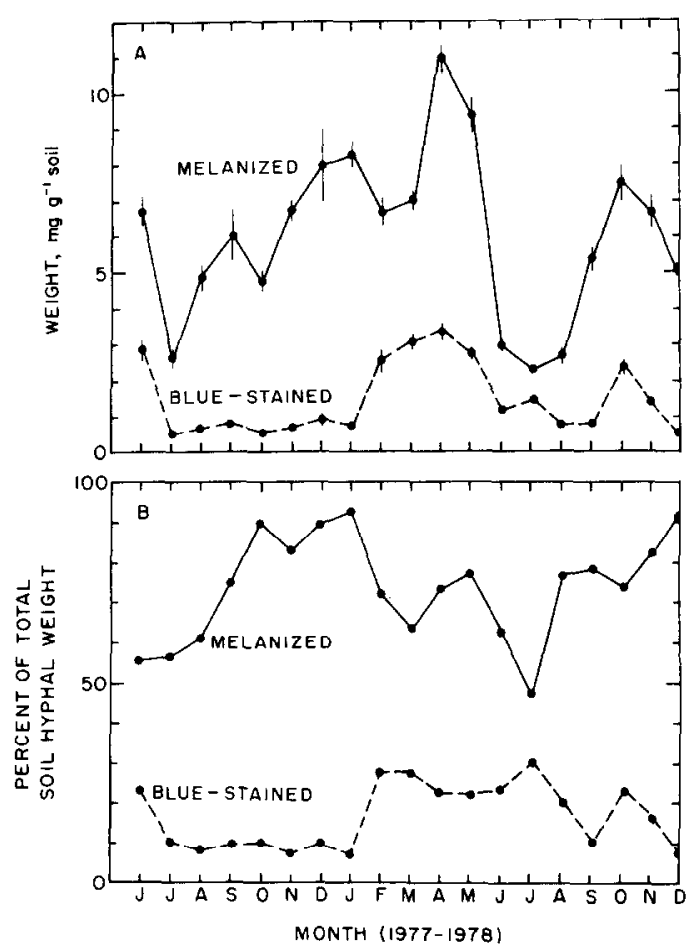

Fig. 5. Monthly weight (A) and percent of total weight (B) of melanized and blue-stained hyphae in soil at Dinner Creek, Oregon. Bars in A indicate standard error; missing bars indicate standard error is $<4 \%$ of the mean.

black and gray), "blue-stained," and "other" hyphae (primarily hyaline). For 19 months, melanized hyphae dominated (Table 2). The weights of melanized litter hyphae ranged from $4.0 \pm 0.22 \mathrm{mg} \mathrm{g}^{-1}$ to a pcak of $17.84 \pm 1.33 \mathrm{mg} \mathrm{g}^{-1}$. Blue-stained litter hyphae ranged from $0.55 \pm 0.03 \mathrm{mg} \mathrm{g}^{-1}$ to $8.44 \pm 0.64 \mathrm{mg} \mathrm{g}^{-1}$. Figure 4 shows the monthly weight and the proportion of the total weight of melanized and blue-stained hyphae in litter.

Weights of melanized hyphae in soil ranged from $220 \pm 8 \mu \mathrm{g} \mathrm{g}^{-1}$ to $1080 \pm 40 \mu \mathrm{g} \mathrm{g}^{-1}$. Blue-stained soil hyphae ranged from $400 \pm 3 \mu \mathrm{g} \mathrm{g}^{-1}$ to $330 \pm 20 \mu \mathrm{g} \mathrm{g}^{-1}$ (Table 2, Fig. 5).

The ubiquitous and morphologically distinctive mycorrhizal fungus Cenococcum geophilum $\mathrm{Fr}$. (Trappe, 1964) was recorded separately. In transmitted light, the thick-walled hyphae are bronze to purple. Data for Cenococcum and all other hyphae for 1-yr show that Cenococcum composed a larger proportion of volume than of length (Table 3 ). For 19 months, it contributed from 13.4 to $45.5 \%$ of litter volume and from 1.2 to $64.8 \%$ of soil hyphal volume.

Table 3. Mean diameter and proportion of total mycelial mass $(\% \pm \mathrm{SE})$ of Cenococcum geophtlum and all other hyphae at Dinner Creek, Oregon

\begin{tabular}{|c|c|c|c|c|c|c|}
\hline & \multicolumn{3}{|c|}{ Litter } & \multicolumn{3}{|c|}{ Soil } \\
\hline & $\begin{array}{c}\text { Mean } \\
\text { diameter }\end{array}$ & $\%$ volume & $\%$ length & $\begin{array}{c}\text { Mean } \\
\text { diameter }\end{array}$ & $\%$ volume & $\%$ length \\
\hline $\begin{array}{l}\text { Cenococcum } \\
\text { Other }\end{array}$ & $\begin{array}{l}4.52(0.10) \\
3.01(0.05)\end{array}$ & $\begin{array}{l}23.7(1.7) \\
76.3(7.6)\end{array}$ & $\begin{array}{l}12.4(0.7) \\
87.6(9.6)\end{array}$ & $\begin{array}{l}4.17(0.12) \\
3.04(0.07) \\
\end{array}$ & $\begin{array}{l}29.4(4.0) \\
70.6(7.1) \\
\end{array}$ & $\begin{array}{l}16.4(1.9) \\
83.6(9.2)\end{array}$ \\
\hline
\end{tabular}




\section{DISCUSSION}

Results of different hyphal studies are not easily compared because of differences in techniques such as the preparation of Jones and Mollison slides (Thomas et al., 1965; Nagel-de Boois and Jansen, 1971) or hyphal measurement, magnification, lighting (Frankland, 1974), and calculation of hyphal volume (Bååth and Söderström, 1979b). Moreover, withinsample variation is typically large. For example, monthly coefficients of variation (standard deviation as a percentage of the mean) for litter hyphal length ranged from 16 to $65 \%$ during this study. In order to reduce this to an average $10 \%$, monthly sampling should increase from 100 to 6588 fields, according to Stein's two-stage estimate of sample size for $P<0.05$ (Steel and Torrie, 1960). It should also be noted that the Jones-Mollison technique results in an underestimate of mycelial mass because of incomplete maceration of organic matter (inevitable in most homogenizers and tissue grinders) and incomplete scparation of hyphal fragments from inorganic soil particles, so that hyphae are pulled to the bottom of the suspension by sinking particles. In addition, some hyphac arc masked by soil particles incorporated in the finished preparations. The work of Bååth and Söderström (1979a) may be most directly compared with our work because of similar techniques in knife blending, phenolic aniline blue-staining, phase contrast microscopy and high magnification $(1000 \times)$, and because we calculated biovolume by the same method.

\section{Hyphal length}

Despite pronounced fluctuation in hyphal length during the wet months of the year (Fig. 1), seasonality is shown primarily by low summer values. The sharp drop in litter hyphal length and volume from November to December 1976 is apparently a "dilution effect" from a large input of uncolonized needle litter during November.

Comparison with other work is difficult because few studies have been extended over time. Nagel-de Boois and Jansen (1971) measured mycelial lengths monthly for $3 \mathrm{yr}$ in an oak-beech forest and found no conclusive evidence of seasonal change. Hyphal length was maximum during autumn and winter in an English Scots pine forest (Nicholas et al., 1965) an in spring in a European black pine plantation (Parkinson et al., 1968). Seasonal samples in a Spanish beech forest (Martinez and Ramirez, 1978) revealed a spring maximum in litter hyphae and a fall maximum in the $A_{11}$ horizon. Laursen and Miller (1977) found spring maxima and summer minima in tundra at Barrow, Alaska, seemingly a reflection of soil moisture and temperature.

The summer drop in hyphal length in Alaska and on our site indicates that seasonal drought influences hyphal biomass. However, it is important to note that monthly increment and decrement of total hyphae may not necessarily represent growth differences but may be influenced by decomposition and soil fauna grazing. Our measurements do not indicate whether the primary cause of fluctuation is rate of growth, mycophagy, or other processes.

Differences in vegetation, climate, and soils make between-site comparisons difficult (Table 4).

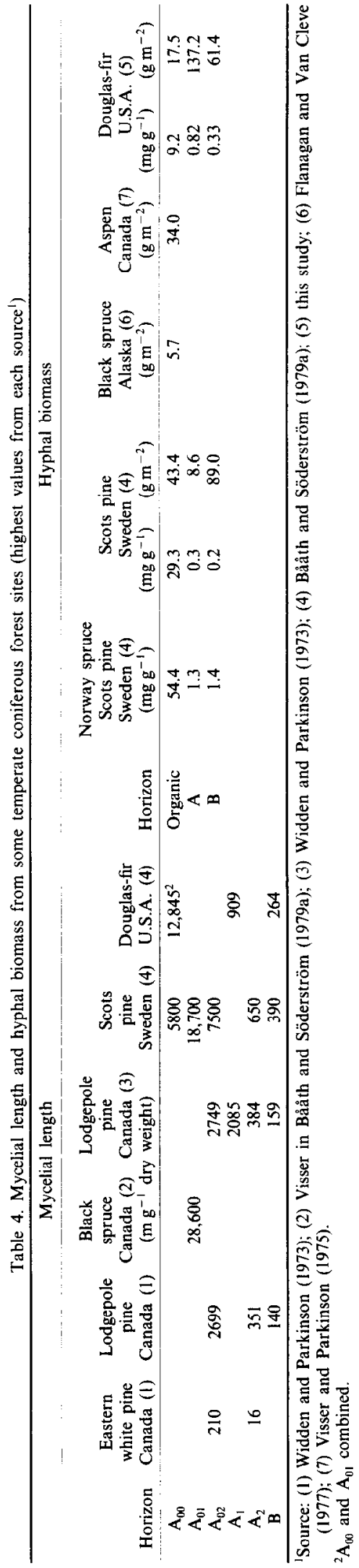


Different soil structures, for example, do not permit direct comparison of hyphal lengths of our study with those of Bååth and Söderström (1979a). The mull humus of our site- $\mathbf{A}_{01}$ and $A_{02}$ horizons ( $F$ and $H$ respectively) - is inseparable and poorly developed compared to the distinct mor humus layers at the Swedish site; therefore, hyphal biomass of the litter there greatly exceeds ours. Our maximum value for surface soil $\left(A_{1}\right)$ is of the same order of magnitude as the $A_{2}$ value of the Swedish site.

Seasonal measurements of hyphal length through the soil profile (Fig. 3) show the highest biomass in the fall, followed by spring, winter and summer. This surface hierarchy is maintained to $50 \mathrm{~cm}$, which indicates that conditions fluctuate sufficiently at that depth to affect hyphal growth significantly. Soil moisture at $50 \mathrm{~cm}$ did not change significantly except during the driest part of summer-23.6\% dw in August 1978 , near $35 \%$ in other seasons. Below $50 \mathrm{~cm}$, hyphal values are nearly the same in all seasons, reflecting the more buffered environment toward the bottom of the profile. The presence of hyphae at $90-100 \mathrm{~cm}$ shows that nutrient supplies are sufficient to sustain some growth. Although some nutrients may be transported from surface horizons to this depth, the hyphae may also derive nutrition from the buried A horizon. No comparable data for a seasonal profile are available for comparison, but several studies have documented a decrease in hyphae with depth (Burges and Nicholas, 1961; Nagel-de Boois and Jansen, 1967; Nicholas and Parkinson, 1967; Parkinson et al., 1968; Widden and Parkinson, 1973; Bååth and Söderström, 1979a).

\section{Hyphal diameter}

Bååth and Söderström (1979a), in the only other publication of mean hyphal diameter through the soil profile that we know, report $2.63 \mu \mathrm{m}$ in the organic layers and $1.90 \mu \mathrm{m}$ in the mineral horizons $\left(\mathrm{A}_{2}\right.$ and B) of a Swedish Scots pine forest. They suggest three possible reasons for narrower hyphae in mineral soil: fewer nutrients, different fungal species inhabiting different horizons (Söderström, 1975; Bissett and Parkinson, 1979a), and abiotic conditions that may be less suitable for growth. Our data support the nutrient hypothesis, in that diameter does not change greatly through the profile. Mean diameter $(3.01 \mu \mathrm{m})$ is the same to $50 \mathrm{~cm}$, below which it decreases only modestly to $2.7 \mu \mathrm{m}(P<0.2)$. Moreover, the mean diameter of Cenococcum does not change significantly in the profile. These changes can be explained in terms of organic-matter distribution. Extensive mixing of humus with surface soil by arthropods and earthworms eliminates the distinct differentiation between organic layers and mineral soil apparent at the Swedish site, where most nutrients are in the mor humus layers. In addition, the buried A horizon of our study site means that organic matter increases slightly from 50 to $70 \mathrm{~cm}$; thus, more uniform distribution may preclude diameter differences based on available nutrients. The mean diameter of $3.01 \pm 0.05 \mu \mathrm{m}$ of this study is at the top of the ranges $1.6-3.0 \mu \mathrm{m}$ and $2.66-3.01 \mu \mathrm{m}$ reported respectively by Båăth and Söderström (1979a) and Visser and Parkinson (1975).

\section{Hyphal biomass}

Biomass data best express fungal mass because they incorporate measures of diameter and thus volume. Bååth and Söderström $(1979 \mathrm{a}, \mathrm{b})$ have discussed the importance of accurate measurement of hyphal diameter in calculating volume; because radius is squared, a relatively small difference in diameter can result in a significant change in volume. For example, weight calculated from volume based on the overall mean diameter, $3.01 \mu \mathrm{m}$, and a length of $3366 \mathrm{~m} \mathrm{~g}^{-1}$, is $10.21 \mathrm{~g} \mathrm{~m}^{-2}$. Weight calculated with separate fragments is $15.80 \mathrm{~g} \mathrm{~m}^{-2}, 35 \%$ larger.

In our study, values based on mean diameter of litter hyphae were $11-41 \%$ smaller than the values derived with the fragment-volume method. Corresponding decreases for surface soil hyphae were $1-47 \%$. The difference in values apparently results from the thicker hyphae, which break into longer pieces during maceration (the longest fragments tend to be the widest). During 5 months, fragments $1-10 \mu \mathrm{m}$ long averaged $3.02 \pm 0.11 \mu \mathrm{m}$ dia; those more than $50 \mu \mathrm{m}$ long averaged $4.54 \pm 0.26 \mu \mathrm{m}$ dia. Use of a single mean diameter does not account for short-term changes which may occur with changes in species dominance. In May 1978, the mean diameter of litter hyphae $1-10 \mu \mathrm{m}$ long was $2.60 \pm 0.14 \mu \mathrm{m}$; in December 1977, the mean diameter was $3.09 \pm 0.18 \mu \mathrm{m}$.

Although hyphal biomass and length fluctuate comparably from season to season, notable monthly differences reflect changes in mean volume of fragments. Between January and February 1977, mycelial length in the surface soil decreased 1.82 times, weight $\left(\mathrm{mg} \mathrm{g}^{-1}\right) 3.47$ times. This indicates an increase in the proportion of narrow hyphae.

The summer increase in mycelial weight $\left(\mathrm{g} \mathrm{m}^{-2}\right)$ from the surface to $60 \mathrm{~cm}$ (Table I) is probably a manifestation of greater soil bulk density, particularly from $20-40 \mathrm{~cm}$ where length decreases from 141 to $133 \mathrm{~m} \mathrm{~g}^{-1}$ but biomass $\left(\mathrm{m}^{-2}\right)$ increases slightly. Extensive hyphal growth near the soil surface in the fall results in hyphal weight $\left(\mathrm{g} \mathrm{m}^{-2}\right)$ decreasing down the profile despite the increase in soil bulk density from the surface to $60 \mathrm{~cm}$. The effect of a moisture gradient on mycelial mass down the profile cannot be determined from our data, but the moisture gradient $(\% \mathrm{dw})$ is minimal during wettest and driest periods. In August 1978, moisture was $21.65 \pm 0.31 \%$ in the top $10 \mathrm{~cm}$ and $26.49 \pm 0.20 \%$ at $90 \mathrm{~cm}$, a range of only $4.84 \%$. A similar narrow range, recorded in May 1978 , was from $38.37 \pm 0.66 \%$ at the surface to $34.50 \pm 0.44 \%$ at $90 \mathrm{~cm}$. In this clay soil, differences of this magnitude do not significantly change water availability.

Distribution of hyphal mass in the profile shifts distinctly with seasons (Table 1), which indicates the importance of seasonal profile sampling to accurate description of distribution. During the fall, about $73 \%$ of the weight $\left(\mathrm{g} \mathrm{m}^{-2}\right)$ is in the top $40 \mathrm{~cm}$ of soil, in the summer about $54 \%$.

Our site may potentially produce $6666 \mathrm{~kg} \mathrm{ha}^{-1} \mathrm{yr}^{-1}$ of fungal mass, most of which turns over in one year (Fogel and Hunt, 1979). The hyphae that decompose annually contain $2.1 \%$ of the total $\mathrm{N}$ stock for the stand (Fogel and Hunt, 1983). Thus, soil hyphae constitute a rapidly cycling pool of nutrients and may 
contribute to ecosystem stability by immobilizing nutrients and thus reducing leaching from the root zone.

Table 4 shows data for mycelial biomass from other sites. Values from the only comparable study, a complete soil profile from Sweden (Bååth and Söderström, 1979a), generally agree with the Dinner Creek values for mineral soil if they are expressed in $\mathrm{mg} \mathrm{g}^{-1}$. A definite contrast appears, however, in the organic layers. Mean annual hyphal weight of litter from Dinner Creek is only one-fifth to one-third that of the Swedish sites, and the fall maximum of $15 \mathrm{mg} \mathrm{g}^{-1}$ is only slightly over half of the Swedish value for Scots pine. However, total mycelial mass in the soil profile, expressed as $\mathrm{g} \mathrm{m}^{-2}$, is much greater at our site due to the greater depth (about $40 \mathrm{~cm}$ rather than $5 \mathrm{~cm}$ ) and the greater hyphal productivity of the A horizon. The annual range of mycelial biomass at Dinner Creek is about 49 to $226 \mathrm{~g} \mathrm{~m}^{-2}$; the value at the Swedish Scots pine site is $8.6 \mathrm{~g} \mathrm{~m}^{-2}$. Hyphal biomass in the B horizon is similar at both sites$89 \mathrm{~g} \mathrm{~m}^{-2}$ in Sweden and $41-82 \mathrm{~g} \mathrm{~m}^{-2}$ at Dinner Creek. Clearly, the significantly greater mycelial mass at Dinner Creek (annual mean $216 \mathrm{~g} \mathrm{~m}^{-2}$ vs $141 \mathrm{~g} \mathrm{~m}^{-2}$ ) is due to the large annual production in the $\mathrm{A}$ horizon.

\section{Color groups}

The amount of blue-stained hyphae in the litter and surface soil was recorded for comparison (Table 2, Fig. 5). The work of Frankland (1975) and Söderström (1979) has shown that blue-stained hyphae do not accurately represent the living fraction. Frankland reported that $34-60 \%$ of hyphae in an English deciduous forest stained blue (mean: $45 \%$ in litter, $54 \%$ in the A horizon); only $15-37 \%$ contained cytoplasm. Söderström found that the proportion of living hyphae (fluorescein diacetate-active) was about 3-6.5 times less than the proportion of blue-stained hyphae. Melanized hyphae do not stain blue; apparently the stain is not taken up or is masked by other pigments. Length of blue-stained hyphae in Söderström's study was $12-16 \%$ of the total hyphal length in the $A_{01}-A_{02}, A_{2}$ and $B$ horizons. Nagel-de Boois and Jansen (1971) reported a marked decrease in blue-stained mycelium from samples of the $L, F$, $\mathrm{H}$ and $\mathrm{A}$ horizons $-80,17,5$ and $4 \%$ of total length, respectively. Bååth and Söderström (1979a) found that blue-stained mycelium ranged from $1-53 \%$ in four Swedish sites. Means for the Scots pine site were 17,12 and $13 \%$ of total length in the organic layers, $\mathrm{A}_{2}$ and $\mathrm{B}$ horizons, respectively.

Our percentages of blue-stained hyphae (Fig. 5, Table 2) are calculated on total weight rather than length, but within this color group, mean total weight and length did not differ significantly $(P>0.05)$. Percentages ranged from 9 to 43 in litter and from 7 to 30 in the surface soil, decreasing slighty from organic horizons to mineral soil. The values are reasonably close to those of the reports just cited.

Bååth and Söderström (1979a) reported that melanized hyphae averaged $18 \%$ of the total hyphal length in the organic layers and $15 \%$ in the surface soil $\left(\mathrm{A}_{2}\right)$ at the Scots pine site. Burges and Nicholas (1961) reported that the number of melanized hyphal fragments decreased sharply from the $H$ to the $A_{1}$ horizon in a glacial sand humus-podzol soil planted to Pinus sylvestris in England. Melanized hyphae comprised $91 \%$ of the fragments in a September sample of the $\mathrm{H}$ horizon and $76 \%$ in the $\mathrm{A}_{1}$ horizon (calculated from Table 5, Burges and Nicholas, 1961). Our data show a much higher contribution by the melanized group than that found in Sweden: $46.6-72.8 \%$ of the total length in litter (mean $59.9 \pm 1.48 \%$ ) and $52.0-90.4 \%$ in soil (mean $68.9 \pm 2.5 \%$ ). The proportion of melanized hyphae in litter, calculated on total weight (Table 2), differs significantly $(P<0.05)$ from the proportion of the total length $(59.9 \%$ vs $66.0 \%)$. Comparable values for surface soil do not differ.

The high proportion of melanized hyphae at our site may be due to summer drought conditions. Mycorrhizae of Cenococcum geophilum, a heavily melanized species more abundant during dry summers, apparently compete poorly with other fungi in moist soil (Palmer, unpublished data, 1954). Worley and Hacskaylo (1959) found that Conococcum increased its mycorrhiza-forming capability as soil moisture was experimentally reduced. Meyer (1964) concluded that the abundance of Cenococcum in strongly rooted mor humus results from a widely fluctuating water economy. Mexal and Reid (1973) reported that Cenococcum tolerated low water potential and grew best at $-1.5 \mathrm{MPa}$, unlike two hyaline species, Suillus luteus (Fr.) S. F. Gray and Thelephora terrestris (Ehrh.) Fr., which grew best at $-0.5 \mathrm{MPa}$.

Table 5. Independent variables made available in multiple regression analyses

\begin{tabular}{ll}
\hline Variable & Explanation \\
\hline For the month & Maximum daily mean \\
Maximum air temperature & Minimum daily mean \\
'Minimum air temperature & Mean hourly temperature \\
'Mean air temperature & Maximum daily mean \\
'Maximum soil temperature & Minimum daily mean \\
Minimum soil temperature & Mean hourly temperature \\
Mean soil temperature & Maximum weekly sample \\
${ }^{1}$ Maximum soil moisture & Minimum wcckly samplc \\
'Minimum soil moisture & Mean of weekly samples \\
${ }^{1}$ Mean soil moisture & Total (mm) \\
'Throughfall & Total dry weight captured (g) \\
Litterfall & Throughfall minus evaporation \\
'Net precipitation & \\
For the season & Cumulative sum of mean soil temperatures \\
${ }^{1}$ Heat sum &
\end{tabular}

Used at least once in hyphal model equations. 
The abundance of melanized hyphae in our seasonally dry climate may indicate that pigmentation is an adaptive advantage for surviving the droughty season. Mikola (1948) reported an optimum growing temperature of $25^{\circ} \mathrm{C}$ for Cenococcum, and we found that an isolate of Cenococcum from the central Oregon Coast Range grew best at $24^{\circ} \mathrm{C}$, about $6^{\circ} \mathrm{C}$ higher than optimum temperature for a hyaline species from the same location, Laccaria laccata Fr. ex. Berk. and $\mathrm{Br}$. (Hunt, unpublished data, 1981). Another factor contributing to this abundance may be that pigmented hyphae decompose more slowly than hyaline hyphae (Bloomfield and Alexander, 1967; Kuo and Alexander, 1967; Hurst and Wagner, 1969).

Cenocaccum hyphae compose a significantly larger proportion of total hyphal volume $(P<0.05)$ than of total length, which reflects a significantly larger diameter than that of other color categories (Table 3). Clearly, when Cenococcum is abundant (maximum: $64.8 \%$ of total soil hyphal volume, December 1977), the mean hyphal diameter of soil samples would be significantly affected; therefore, calculations based on a single mean diameter might seriously underestimate biomass in some months.

The physiological significance of the larger diameter is unknown. Surface area is greater than that of most other hyphae, but the surface-to-volume ratio is smaller. Lumen volume is probably not significantly greater than that of most other hyphae.

\section{Correlation with environmental factors}

Monthly changes in hyphal biomass were analyzed through simple and multiple regression. Length $\left(\mathrm{m} \mathrm{g}^{-1}\right)$ and weight $\left(\mathrm{mg} \mathrm{g}^{-1}\right)$ for each substrate served as dependent variables, and 13 abiotic factorswhich except for literfall were derived from temperature and moisture data-served as independent variables (Table 5).

The 27 hyphal values for litter and soil (top $5 \mathrm{~cm}$ ) were regressed against abiotic factors separately. Four curve types were fitted in each case: linear $(y-a+b x)$, exponential $\left(y=a e^{b x}\right)$, logarithmic $(y=a+b \ln x)$, and power $\left(y=a x^{b}\right)$. Coefficients of determination $\left(\mathrm{r}^{2}\right)$ did not exceed 0.39 for any pair tested. Multiple regression equations were generated by the stepwise addition of the Statistical Package for the Social Sciences available at Oregon State University. Each equation contained three to six independent variables.

Two environmental factors, maximum soil moisture and net precipitation, appeared in all four equations and nine of thirteen independent variables were used (Table 5). The amount of variation accounted for was $41.84 \%\left(\mathrm{~m} \mathrm{~g}^{-1}\right)$ and $45.81 \%\left(\mathrm{mg} \mathrm{g}^{-1}\right)$ for litter hyphae, $54.92 \%\left(\mathrm{~m} \mathrm{~g}^{-1}\right)$ and $66.00 \%\left(\mathrm{mg} \mathrm{g}^{-1}\right)$ for soil hyphae. We know of only one other multiple regression analysis of hyphal mass. Dowding and Widden (1974) accounted for $44 \%$ of the variation in mycelial length in terms of soil moisture, $\mathrm{pH}$ and temperature.

Temperature and moisture are most often correlated with changing hyphal mass. Moisture and soil organic matter are highly correlated, so their separate influence is nearly impossible to determine. Soil moisture (and organic matter) is cited as the primary controlling factor by Söderström (1979), Parkinson et al. (1968), Laursen and Miller (1977), and Dowding and Widden (1974). Flanagan and Van Cleve (1977) concluded that temperature was most important in an Alaskan black spruce taiga ecosystem. Bissett and Parkinson (1979b) used multiple regression analyses to determine the variables most affecting distribution and community composition of soil fungi in three Canadian alpine habitats. They concluded that temperature, moisture, available potassium, and soil $\mathrm{pH}$ were most important. Nicholas et al. (1965) noted an increase in mycelial production 1-2 months after maximum litterfall followed by rain leaching in England.

Our results indicate that available data cannot produce an adequate model to explain the biomass fluctuations observed. Several possibly confounding elements can be mentioned. First, large standard errors make monthly means difficult to ascertain. Second, the data set of 27 monthly values is too small for the number of independent variables; ideally, each independent variable would be represented by ten data points. Third, as we have noted, measurement of total hyphae does not necessarily indicate production because decomposition and grazing by soil fauna are not taken into account. Also, all possible influencing environmental factors have not been measured-for example, the effect of root exudates on growth of associated mycorrhizal fungi. Finally, a drought during the first year of this study (precipitation $45 \%$ of normal) may have drastically altered typical fungal growth patterns. Our results support the view of Dowding and Widden (1974) that relationships between fungal growth and the environment are so complex that analyses of linear relationships are not likely to provide satisfactory explanations. Because fungal species vary greatly in their response to the complex of environmental factors, more useful information may be obtained by study of individual species.

Acknowledgements-This research was supported by a National Science Foundation grant and was conducted in cooperation with the U.S. Forest Service, Pacific Northwest Forest and Range Experiment Station, Forestry Sciences Laboratory, Corvallis, OR. We thank Gary Blanchard for help in site selection and for permission to use land owned by Starker Forests. This is Paper 1647, Forest Research Laboratory, Oregon State University, Corvallis.

\section{REFERENCES}

Bååth E. and Söderström B. E. (1979a) Fungal biomass and fungal immobilization of plant nutrients in Swedish coniferous forest soils. Revue d'Écologie et de Biologie du Sol 16, 477-489.

Bååth E. and Söderström B. E. (1979b) The significance of hyphal diameter in calculation of fungal biovolume. Oikos 33, 11-14.

Bissett J. and Parkinson D. (1979a) Fungal community structure in some alpine soils. Canadian Journal of Botany 57, 1630-1641.

Bissett J. and Parkinson D. (1979b) Functional relationships between soil fungi and environment in alpine tundra. Canadian Journal of Botany 51, 1642-1659.

Bloomfield B. J. and Alexander M. (1967) Melanins and resistance of fungi to lysis. Journal of Bacteriology 93, 1276-1280.

Boois H. M. de (1976) Fungal development on oak leaf litter and decomposition potentialities of some fungal species. Revue d'Écologie et du Biologie du Sol 13, 437-449. 
Burges A. and Nicholas D. P. (1961) The use of soil sections in studying the amount of fungal hyphae in soil. Soil Science 92, 25-29.

Cochrane V. W. (1958) Physiology of Fungi. Wiley, New York.

Dowding P. and Widden P. (1974) Some relationships between fungi and their environment in tundra regions. In Soil Organisms and Decomposition in Tundra (A. J. Holding, O. W. Heal, S. F. Maclean $\mathrm{J}_{\mathrm{r}}$ and P. W. Flanagan, Eds), pp. 123-150. Tundra Biome Steering Committee, Stockholm, Sweden.

Flanagan P. W. and Van Cleve K. (1977) Microbial biomass, respiration and nutrient cycling in a black spruce taiga ecosystem. In Soil Urganisms As Components of Ecosystems (U. Lohm and T. Persson, Eds), Ecological Bulletin 25, 261-273.

Fogel R. and Hung G. (1979) Fungal and arboreal biomass in a Western Oregon Douglas-fir ecosystem: distribution patterns and turnover. Canadian Journal of Forest Research 9, 245-256.

Fogel R. and Hunt G. (1983) Contribution of mycorrhizae and soil fungi to nutrient cycling in a Douglas-fir ecosystem. Canadian Journal of Forest Research 13, 219-232.

Frankland J. C. (1974) Importance of phase-contrast microscopy for estimation of total fungal biomass by the agar-film technique. Soil Biology \& Biochemistry 6, 409-410.

Frankland J. C. (1975) Estimation of live fungal biomass. Soil Biology \& Biochemistry 7, 339-340.

Hurst H. M. and Wagner G. H. (1969) Decomposition of $\mathrm{C}^{14}$-labeled wall and cytoplasmic fractions from hyaline and melanic fungi. Soil Science Society of America Proceedings 33, 707-711.

Jones P. C. 'T. and Mollison J. E. (1948) A technique for the quantitative estimation of soil micro-organisms. Journal of General Microbiology 2, 54-69.

Knezevich C. A. (1975) Soil Survey of Benton County Area, Oregon. U.S. Department of Agriculture, Soil Conservation Service, U.S. Government Printing Office, Washington, DC.

Kuo M. J. and Alexander M. (1967) Inhibition of the lysis of fungi by melanins. Journal of Bacteriology 94, 624-629.

Laursen G. A. and Miller O. K. Jr (1977) The distribution of fungal hyphae in arctic soil on the tundra biome site, Barrow, Alaska. In The Belowground Ecosystem: A Synthesis of Plant Associated Processes (J. K. Marshall, Ld.), pp. 205-214. Range Science Department, Science Series No. 26, Colorado State University, Fort Collins.

Martinez A. T. and Ramirez C. (1978) Microfungal biomass and number of propagules in an andosol. Soil Biology \& Biochemistry 10, 529-531.

Mexal J. and Reid C. P. P. (1973) The growth of selected mycorrhizal fungi in response to induced water stress. Canadian Journal of Botany 51, 1579-1588.

Meyer F. H. (1964) The role of the fungus Cenococcum graniforme (Sow.) Ferd. et Winge in the formation of mor. In Soil Micromorphology (A. Jongerius, Ed.), pp. 23-31. Elsevier, Amsterdam.

Mikola P. (1948) On the physiology and ecology of Cenococcum graniforme especially as a mycorrhizal fungus of birch. Communications Instituti Forestalis Fenniae 36, $1-104$.

Nagel-de Boois H. M. and Jansen E. (1967) Hyphal activity in mull and mor of an oak forest. In Progress in Soil Biology (O. Graff and J. E. Satchell, Eds), pp. 27-36. Verlag Friedrich, Braunschweig.

Nagel-de Boois H. M. and Jansen E. (1971) The growth of fungal mycelium in forest soil layers. Revue d'Ecologie et de Biologie du Sol 8, 509520.

Nicholas D. P. and Parkinson D. (1967) A comparison of methods for assessing the amount of fungal mycelium in soil samples. Pedobiologia 7, 23-41.

Nicholas D. P., Parkinson D. and Burges N. A. (1965) Studies of fungi in a podzol II. Application of the soil sectioning technique to the study of amounts of fungal mycelium in the soil. Journal of Soil Science 16, 258-269.

Parkinson D., Balasooriya I. and Winterhalder K. (1968) Studies on fungi in a pinewood soil III. Fungal growth and total microbial activity. Revue d'Écologie et de Biologie du Sol 4, 637-645.

Saitô T. (1955) The significance of plate counts of soil fungi and the detection of their mycelia. Ecological Review 14, 69-74.

Söderström B. E. (1975) Vertical distribution of microfungi in a spruce forest soil in the South of Sweden. Transactions of the British Mycological Society 65, 419-425.

Söderström B. E. (1979) Some problems in assessing the fluorescein diacetate-active fungal biomass in the soil. Soil Biology \& Biochemistry 11, 147-148.

Steel R. G. D. and Torrie J. H. (1960) Principles and Procedures of Statistics. McGraw-Hill, New York.

Thomas A., Nicholas D. P. and Parkinson D. (1965) Modifications of the agar film technique for assaying lengths of mycelium in soil. Nature 205, 105.

Trappe J. M. (1964) Mycorrhizal hosts and distribution of Cenococcum graniforme. Lloydia 27, 100-106.

Visser S. and Parkinson D. (1975) Fungal succession on aspen poplar leaf litter. Canadian Journal of Botany 53, 1640-1651.

Widden P. and Parkinson D. (1973) Fungi from Canadian coniferous forest soils. Canadian Journal of Botany 51, 2275-2290

Worley J. F. and Hacskaylo E. (1959) The effect of available soil moisture on the mycorrhizal association of Virginia pine. Forest Science 5, 267-268. 